\title{
ARASTIRMA MAKALE
}

\section{Yerinde Yaşlanma ve Konutlarda Yaşama Mekânlarının Tasarımı ${ }^{1}$}

\author{
Hande EYÜBOĞLU2a \& Tülay ZORLU ${ }^{\text {b }}$ \\ aSamsun Üniversitesi Mimarlık ve Tasarım Fakültesi, İç Mimarlık ve Çevre Tasarımı Bölümü, Samsun / Türkiye \\ bKaradeniz Teknik Üniversitesi Mimarlık Fakültesi, İç Mimarlık Bölümü, Trabzon / Türkiye \\ ORCID: 0000-0003- 0504-2886 / ORCID: 0000-0001-5096-7146
}

\begin{abstract}
ÖZET
Fiziksel, algısal, zihinsel yeti kayıplarının ortaya çıktığı bir dönem olarak yaşlılık, yaşam alanının sınırlandığı bir dönemdir. Bu dönemde gündelik yașamın büyük bölümü konut odaklı hale gelmektedir. Bu durum hem yaşam memnuniyetinde hem de aktif ve kaliteli yaşlanmada yaşlı kullanıcıların konut ve yakın çevre özelliklerinin önemini ortaya koymaktadır. Yaşlılık sürecindeki fiziksel, psikolojik, sosyal ve ekonomik değişimler yaşlı kullanıcıların gereksinmelerini ve buna bağlı olarak fiziksel çevrelerinden beklentilerini değiştirmektedir. Bu bağlamda konutun iç mekânı ve bulunduğu çevrenin, yaşlı kullanıcıların fiziksel özelliklerine, değișen gereksinim ve isteklerine uygun şekilde düzenlenmiş olması büyük önem taşımaktadır. Yaşlılık döneminde, gün içinde konutta en çok vakit geçirilen mekânlardan biri olan yaşama mekânlarında da mekân örgütlenmesi ve donatı özellikleri yaşlı kullanıcıların gereksinim ve isteklerine uygun olmalıdır.

Bu çalışmanın amacı, yerinde yaşlanmada yaşlı bireylerin konutlardaki yaşama mekânlarının iç mekân düzenlemesine yönelik tasarım prensipleri ve donatı özelliklerini ortaya koymaktır. Bu amaç doğrultusunda yaşlı kullanıcıların konutlarındaki yaşama mekânlarında şikâyetçi oldukları hususların, ihtiyaç ve beklentilerinin belirlenmesi hedeflenmiştir. Calışma kapsamında 65 yaş ve üzeri 70 kullanıcıyla görüșmeler gerçekleștirilmiștir. Calıșmada yașlı kullanıcıların yașama mekânlarında gerçekleştirdikleri eylemler, memnun ve şikâyetçi oldukları hususlar, konuta iliş̧kin ihtiyaç, istek ve beklentileri belirlenmiş ve iç mekân tasarımına yönelik tasarım/düzenleme önerileri sunulmuştur.
\end{abstract}

\section{Aging in place and design of living spaces in housings}

\section{MAKALE GEÇMİȘI}

Geliş 27 Temmuz 2021

Kabul 21 Aralık 2021

\section{ANAHTAR KELIMELER}

Yerinde yaşlanma, yaşlı kullanıcı, konut, iç mekân, yaşama mekânı

\begin{abstract}
The old age period, as a period in which physical, perceptual and mental ability losses occur, is a period in which the living space is limited. During this period, most of the daily life becomes residential-oriented. This situation also reveals the importance of housing and close environment characteristics of elderly users in both life satisfaction and active and quality aging. Physical, psychological, social and economic changes in the aging process change the needs of elderly users and accordingly their expectations from their physical environment. For this reason, it is of great importance that the interior of the house and its environment are arranged in accordance with the physical characteristics, changing needs and wishes of the elderly users, in order for them to continue their lives without the need for anyone else. For aging in place, in living spaces as the places where the most time is spent during the day, the space organization and equipment features should be suitable for the needs and wishes of the elderly users. The aim of this study is to reveal the design principles and equipment features for the interior arrangement of the living spaces of the elderly people in aging in place. For this purpose, it is aimed to determine the issues, needs and expectations of the elderly users in their living spaces in their houses. Within the scope of the study, interviews were conducted with 70 users aged 65 and over. In the study, the actions performed by the elderly users in their living spaces, the issues they are satisfied with and complain about, their needs, wishes and expectations regarding the housing were determined, and then design/arrangement suggestions for interior design were presented in line with these data.
\end{abstract}

\section{ARTICLE HISTORY}

Received 27 July 2021

Accepted 21 Dec 2021

\section{KEYWORDS}

Aging in place, elderly user, housing, interior, living space

\footnotetext{
1 "Yaşlılık, Yerinde Yaşlanma ve Konut” başlıklı Yüksek Lisans tezinden üretilen bu çalışma “11. Ulusal Yaşlılık Kongresi"nde sözel bildiri olarak sunulmuştur.

2 Sorumlu Yazar e-mail: hande.eyuboglu@samsun.edu.tr

Makalenin Kaynak Olarak Gösterimi: Eyüboğlu, H., \& Zorlu, T. (2021). Yerinde yaşlanma ve konutlarda yaşama mekânlarının tasarımı. Yaşlı Sorunları Araştırma Dergisi (YSAD) / Elderly Issues Research Journal (EIRJ), 14(2), 5969. doi: 10.46414/yasad.974658
} 


\section{GİRIŞ}

Sağlık, teknoloji, sosyal ve ekonomik alandaki gelişmeler ve yaşam standartlarının yükselmesi ile birlikte ortalama yaşam süresinin uzamasına bağlı olarak dünya nüfusu giderek yaşlanmaktadır. Dünyada olduğu gibi Türkiye'de de yaşlı nüfusta hızlı bir artış görülmektedir. TUIK'in 2020 yılı verilerine göre Türkiye'deki toplam nüfusun $\% 9,5$ 'ini yaşlılar olușturmakta ve bu oranın 2030 yılında \%12,9'a 2040 yılında \%16,3'e çıkması beklenmektedir (TUİK, 2021). Yaşlılık, kronolojik, biyolojik, sosyal, toplumsal ve ekonomik açlardan farklı boyutlarıyla ele alınan bir olgudur. Yaşlılık döneminde bireylerde çeșitli kronik rahatsızlıkların yanı sıra, hareket kısitlılıkları, duyusal ve zihinsel yeti kayıpları görülmektedir. Yaşlı bireylerin kas ve dokularında meydana gelen esneklik kaybı uzanma, eğilme ve dönme hareketlerini güçleștirirken hareket yetilerindeki azalmaya bağlı olarak uzun mesafeleri yürümede de güçlük çekmektedirler. Ayrıca eklemlerde meydana gelen ağrı, güçsüzlük gibi rahatsızlıklar nedeniyle dirsekler, eller, parmaklar rahatlıkla hareket ettirilemediğinden el becerileri azalmakta, güç gerektiren kavrama, tutma, sıkma, itme, çekme ve döndürme hareketlerinin yapılması güçleştirmektedir. Görme yetisindeki kayıplar sebebiyle renkleri, şekilleri ayıt etme zorlaşırken görüş alanı da giderek azalmaktadır. Yaşlanmayla birlikte işitme duyusunda da azalmalar meydana gelmekte ve buna bağlı olarak sesli uyarıların fark edilmesi güçleşmektedir. Yaşlılık döneminde merkezi sinir sisteminde, zihinsel süreçlerde koordinasyonun azalması, algılama, kavrama, becerilerindeki kayıplar ile ilişkili olarak araç-gereç ve ekipmanların kullanımını hatırlama ve problem çözme yetileri olumsuz yönde etkilenmektedir (Johnson, Duncan, Gabriel \& Carter, 1999; Hazer, 2012).

Yaşlılık döneminde ortaya çıkan bu rahatsızlık ve yeti kayıplarına bağlı olarak yașlı bireylerin kimseye muhtaç olmadan kendi kendine yetebilmeleri güçleşmekte yaşam alanı sınırlanmakta ve gündelik yaşam aktivitelerinin büyük bir bölümü konut odaklı hale gelmektedir. Çeşitli yeti kayıplarının yaşandığı bir dönem olan yașlilık döneminde fiziksel çevreye ilişkin gereksinme ve beklentiler de değişmektedir.

Barınma ihtiyacının giderilmesi için dünyanın hemen hemen her yerinde benimsenen model yaşlı bireylerin kendi kendilerine yetebildikleri sürenin mümkün olduğunca uzatılarak, yaşam boyu kendi evlerinde yaşayabilmeleri yani yerinde yaşlanmaya yöneliktir (İmamoğlu, 2015; Kalınkara \& Kapıkıran, 2017). Bu dönemde bireylerin alışkın oldukları yerde kendi evlerinde yaşlanabilmeleri yaşam memnuniyetlerini olumlu yönde etkilemektedir.

Aktif ve kaliteli bir yaşlılık dönemi geçirmede hem konutun yakın çevresinin hem de konuttaki mekânların bireylerin değişen ihtiyaç ve beklentilerine uygun olarak düzenlenmiș olması önemlidir. Yerinde yaşlanma için konuttaki tüm mekânlarda olduğu gibi gün içinde en çok vakit geçirilen yaşama mekânları da bireylerin yaşlılık dönemindeki gereksinim ve isteklerine cevap verebilecek özelliklerde düzenlenmiş olmalıdır.
$\mathrm{Bu}$ çalışmanın amacl, yerinde yaşlanmada yaşlı bireylerin konutlardaki yaşama mekânlarının iç mekân düzenlemesine yönelik tasarım prensipleri ve donatı özelliklerini ortaya koymaktır. $\mathrm{Bu}$ amaç doğrultusunda çalışma kapsamında 65 yaş ve üzeri yaş grubu kendi evinde bağımsız olarak yașamını devam ettiren yaşlı kullanıcıların yaşama mekânlarında gerçekleștirdikleri eylemler, memnun oldukları özellikler, şikâyetçi oldukları hususlar, mekân büyüklüğü, iç mekân düzenlemesi, donatı özellikleri, fiziksel konfor koşullarına ilişkin istek ve beklentileri belirlenmiș ve ardından bu veriler doğrultusunda iç mekân tasarımına yönelik tasarım/düzenleme önerileri sunulmuştur.

\section{Yerinde Yaşlanma}

Yerinde yaşlanma bireylerin yaş, gelir ve yeteneklerine bakılmaksızın kendi evlerinde ve toplumda güvenli, bağımsız ve rahat bir şekilde yaşama yeteneği olarak tanımlanmaktadır (Kalınkara \& Arpacl, 2016). Bir bașka ifade ile yerinde yașlanma yaşlı bireylerin bir kuruma taşınmaları yerine alışkın oldukları yerde, kendi evlerinde mümkün olduğunca uzun bir süre bağımsız devam ettirmesidir (Cook, Yearns \& Martin, 2005:85; Riche, 2008; Fiessel, Kulyk, Peel, Pfeifer, Robert \& Statler, 2013; Kalınkara \& Kapıkıran, 2017). Yerinde yaşlanma kurum bakımına olan bağımlılığı büyük ölçüde azaltırken, yaşlı bireylere kendi yaşamları ve çevre üzerinde denetim ve kontrol hakkı sağlayarak yaşamlarını bağımsız bir şekilde sürdürme imkânı sunmaktadır. Yaşlılık döneminde bağımsızlık duygusu aynı zamanda onların yașam memnuniyetlerini ve yaşam kalitelerini arttırmaktadır (Kalınkara \& Arpacı, 2016).

Yerinde yașlanma ile ilgili yapılmıș çalıșmalar yașlı bireylerin kendilerini evlerinde güvende hissettiklerini ve evlerinde yaşlanmak istediklerini göstermektedir (Pinto, Medici, Van Sant, Bianchi, Zlotnicki \& Napoli, 2005; Lansley, Flanagan, Goodacre, Turner-Smith \& Cowan, 2005; Kalınkara \& Arpacl, 2013; Kalınkara \& Kalaycı, 2019). Çeşitli yeti kayıpları nedeni ile yaşam alanları sınırlanan yaşlı bireylerin gündelik yaşamlarının büyük bölümü konut odaklı hale gelmektedir. Yaşlılık dönemindeki fiziksel, psikolojik, sosyal ve ekonomik değișimler yaşlı kullanıcıların gereksinmelerini ve beklentilerini değiştirmektedir. Alışkın oldukları çevrede yaşlanmak yaşlı kullanıcıların yaşam memnuniyetlerinde önemli bir faktördür. $\mathrm{Bu}$ nedenle yerinde yaşlanabilmenin sağlıklı bir şekilde sağlanabilmesi için konutların yaşlı kullanıcıların değișen ihtiyaç ve isteklerine uygun olarak tasarlanmış olması önemlidir (Zorlu \& Onur, 2019). Konutta temel gereksinmelerin karşılanmasına yönelik mekânlar; yaşama mekânları, mutfak, yatak odası ve banyo/tuvalet olarak sıralanabilir. Bu çalışma kapsamında yerinde yaşlanmanın gerçekleşebilmesi için pek çok bilimsel araştırmalarda da belirtildiği üzere (Lawlor \& Thomas, 2008; Judd, Olsberg, Quinn, Groenhart \& Demirbilek, 2010; Kalınkara, Tezel \& Zorlu, 2016; Zorlu, 2015; Zorlu, 2017; Özer Baș, 2019; Zorlu \& Onur, 2019) yaşlı bireylerin günlük yaşantılarında konutta en çok vakit geçirdikleri mekân olan yaşama mekânları ele alınmaktadır. 
Yerinde Yaşlanmada Konut Yaşama Mekânlarının Tasarımı

Konutta yaşlı kullanıcıların gün içinde en çok vakitlerini geçirdikleri yer yaşama mekânlarıdır. Yaşama mekânları yaşlı kullanıcıların oturma, dinlenme, televizyon izleme, misafir ağırlama/sosyalleşme, hobi aktivitelerini ve mutfak ile bir arada çözüldüğü durumlarda aynı zamanda yemek yeme eylemlerini gerçekleştirdikleri bir mekândır. Yaşlı kullanıcılar günün büyük bir bölümünü konutlarının yaşama mekânında geçirdikleri için yaşama mekânlarının iç mekân özellikleri, yaşama mekânının konuttaki diğer mekânlar ve dış mekân ile ilişkisi daha da önem kazanmaktadır.

Yaşama mekânlarının mekân organizasyonunda mekânın boyutları, donatı ve mobilyaların yerleşim biçimi, yoğunluğu önemli bir yere sahiptir. Yaşama mekânları yaşlı kullanıcıların herhangi bir zorluk yaşamadan eylemlerini rahatllkla gerçekleştirebilecekleri yeterli büyüklükte olmalıdır. Mekân büyüklüğü yaşama mekânında gerçekleștirilecek eylemlerin çeşitliliğine bağlı olarak belirlenmelidir (Zorlu, 2015; Zorlu, 2017). Mekânda gerçekleștirilecek eylemlerin sayısı arttıkça yașama mekânın büyüklüğü de eylemlerin kolay ve rahat bir şekilde gerçekleştirilmesine imkân verecek şekilde artmalıdır.

Yaşlı kullanıcıların konut yaşama mekânları da mekânı örgütlerken mobilya yerleşiminde koltuklar sohbeti aksatmayacak şekilde düzenlenmelidir. Özellikle televizyonun karşısında kullanıcıların uzanarak televizyon izleyebilecekleri bir koltuk yer almalıdır. Mekanın örgütlenmesinde yaşlılık döneminde kullanıcıların hareket kısıtlılıkları göz önünde bulundurularak yeterli sirkülasyon alanı bırakılmalıdır. Özellikle baston, yürüteç ya da tekerli sandalye kullanımları göz önünde bulundurularak rahat bir dolașım için en az 150x150cm'lik bir alan bırakılmalıdır (İlçe, İlçe \& Dıramalı, 2007; Zorlu, 2017). Sirkülasyon alanlarının üzerinde takılarak düşmeye sebep olacak herhangi bir donatı ve mobilya olmamalıdır. Yaşama mekânının tasarımında kullanıcıların bu mekânda gerçekleştirecekleri eylemlerde ihtiyaç duyacakları yeterli sayıda donatı ve mobilyalar yer almalıdır. Donatı ve mobilyaların rahatlıkla kullanılabilmeleri için etrafında yeterli boşluklar bırakılmalıdır (Harrington \& Harrington, 2000; Kirby, 2004; İlçe vd., 2007; Zorlu, 2017).

Yașama mekânında yer alan donatıların form ve boyutsal özellikleri yaşlı kullanıcıların kullanımına uygun olmalıdır. Koltuk, kanepe ve sandalyeler yaşlı kullanıcıların kolaylıkla oturup kalkabilmeleri için çok alçak, çok yüksek, çok derin, çok yumuşak ya da çok sert olmamalıdır ve oturup kalkmaya yardımcı olmak için kolçaklı olmalıdır. Yaşama mekanında koltuk ve kanepeler yaşlı kullanıcıların antropometrik boyutlarına uygun, rahatlıkla oturabilecekleri gerektiğinde uzanabilecekleri özelliklerde tasarlanmıș olmalıdır (Kirby, 2004; Safak, Erkal \& Çopur, 2005; İlçe vd., 2007; Zorlu, 2017). Yaşama mekânındaki donatı ve mobilyalar sivri köşelere ve girintili çıkıntılı yüzeylere sahip olmamalıdır. Mobilya ve donatılarda açık, kolay algılanabilirlik açısından duvar ve zeminden farklı renkler tercih edilmelidir (Bakker, 1997:43; Pinto vd., 1997). Depolama birimleri görünürlük ve kullanım kolaylığı açısından açık raflı veya cam kapaklı olmalı; boyutları belirlenirken yaşlı kullanıcıların uzanma ve erişme mesafeleri göz önünde bulundurulmalıdır (Anonim, 2016; Zorlu, 2017).

Yaşama mekânlarının tasarımında mekân boyutu, örgütlenme ve donatı/mobilya özelliklerinin yanı sıra malzeme, detay çözümlemeleri ve fiziksel konfor koşulları da göz önünde bulundurulmalıdır. Zemin kaplama malzemesi kayma ve düşmeye sebebiyet vermeyecek özellikte olmalı, kayan halı ve kilimler kullanılmamalıdır (Anonim, 2005; Şafak vd., 2005; İlçe vd., 2007; Anonim, 2016). Yaşama mekânının zemininde kot farkları mevcut ise yaşlı kullanıcıların yüzey seviyelerindeki değişikliği kolaylıkla algılayabilmeleri ve herhangi bir kaza yașamamaları için zemin kaplama malzemelerinde renk veya doku farklılıkları olușturulmalıdır. Yașama mekânlarında duvar yüzeylerinde gözü yoran ve kamaşmaya sebep olacak parlak renkler tercih edilmemelidir. Yüzey boyaları yașlı kullanıcıların sağlığını olumsuz yönde etkilemeyen, yüksek oranda kimyasal madde içermeyen ve zehirli gazlar yaymayan özelliklere sahip olmalıdır (Anonim, 2016).

Yaşama mekânının gün ışı̆̆ı alması yaşlı kullanıcılar için oldukça önem taşımaktadır. Yaşama mekânında gün ışığını mekâna alan yeterli sayıda, daha düşük eşik yüksekliğine sahip, kullanıcıların antropometrik boyutları dikkate alınarak tasarlanan alçak ve geniș pencereler olmalıdır. Pencereler içerden kolaylıkla açılmalı ve pencere kolları yaşlı kullanıcıların rahatlıkla kavrayabileceği basit bir şekilde tasarlanmalıdır (Vallins, 1998; İlçe vd., 2007; Anonim, 2021).

Yaşama mekânları, yaşlı kullanıcılara uygun fiziksel konfor koșullarını sağlamalıdır. Vakitlerinin büyük bir bölümünü yaşama mekânlarında geçirdikleri için bu mekânın ısıl konfor özelliklerinin yaşlı kullanıcılara uygun olması önemlidir (Harrington \& Harrington. 2000; Kalınkara \& Kalaycı, 2019). Yaşlı kullanıcılar için yaşama mekânının ideal oda sıcaklığı kış şartlarında ortalama 21 derece, yaz aylarında ise ortalama 24 derecedir (Okumus, 2014). Yaşama mekânlarında yaşlı kullanıcıların eylemlerini rahatlıkla ve doğru bir şekilde gerçekleştirebilmeleri için mekânın görsel konfor özellikleri yașlı kullanıcılara uygun olmalıdır. Bu nedenle, gün ışığı kullanımı ve yapay aydınlatma sistemlerinin tasarımı yaşama mekânında kullanıcılar açısından önemlidir (Fernández-Portero, Alarcón, \& Padura, 2017). Yașama mekânlarında görsel konfor koșullarının sağlanmasında gün ışığının yeterli olmadığı durumlar için yeterli aydınlık düzeyi sağlayacak genel ve bölgesel aydınlatma yapılmıș olmalıdır. Yaşama mekânlarında işitsel konfor koşullarının sağlanması için dışarıdan gelebilecek gürültülere karşı ses izolasyonu yapılmalıdır (Fox, Kenny, Day, O'Connell, Finnerty \& Timmons, 2017; Feng, Chen, Zhu \& Xiongl, 2018).

Yaşama mekânlarında ışık anahtarları mekânın girişine yakın bir bulunmalı ve yerden en çok 120 cm'den yükseklikte erișebilir bir șekilde konumlandırılmalıdır. Prizler ise yerden $70 \mathrm{~cm}$ yüksekliğe yerleștirilmelidir (Vallins, 1998; İlçe vd., 2007). Yaşlı kullanıcılar artan yaşlarına bağlı olarak 
yaşama mekânlarında hareket etmede zaman zaman güçlük yaşayabilmektedir. Günümüzde uzaktan kumanda ile yönetilen ısıtma, soğutma, aydınlatma vb. sistemlerin kullanımı yaşlılık döneminde kullanıcıların gündelik yaşamlarını kolaylaştıran uygulamalardır (Anonim, 2016).

Yerinde yaşlanmada konut yaşama mekânlarının tasarımında iç mekân özelliklerinin yanı sıra konut içi konumları ve diğer mekânlar ile ilişkisi de oldukça önemlidir. Yaşama mekânları konut içerisinde mutfak ve yarı açık mekânlara yakın bir yerde konumlandırılmalı ya da bu mekânlar ile doğrudan ilişkili olmalıdır. Yaşama mekânları büyüklüğünün yeterli olması durumunda mutfak ile birlikte, açık bir düzende planlamalıdır. Açık düzenlemeler, yaşlı kullanıcıların yaşama mekânlarında vakit geçirirken ihtiyaç duymaları halinde kısa sürede mutfağa ulaşabilmeleri için önemlidir (Anonim, 2016).

Yaşlılık döneminde hareket alanları kısıtlanan yaşlı kullanıcıların yaşama mekânlarının yarı açık mekânlar ile doğrudan ilişkili olması yaşam kaliteleri ve memnuniyetlerini arttırmaktadır. Günün büyük bir bölümünü konutlarında geçiren yaşlı kullanıcılar için yarı açık mekânlar/balkonlar dıșarısı ile iletișim kurdukları, komşuları ile sosyalleștikleri yerlerdir (Lawton \& Nahemow, 1987; Talbot \& Kaplan, 1991; Gardner, 2011; Fox vd., 2017; Şentürk \& Kurtkapan, 2017). Bu nedenle yaşama mekânları ile ilişkili yarı açık mekânlar yaşlı kullanıcıların oturup dinlenmelerine, dışarıyı izlemelerine ve çeşitli hobi aktivitelerini gerçekleştirmelerine imkân veren yeterli bir büyüklükte olmalıdır. Hareket kısıtlılıklarına bağlı olarak sınırlanan ve konut odaklı hale gelen günlük yaşam rutininde konuttaki yaşama mekânlarının dış mekân ile ilișkisi önem kazanmaktadır. Yașama mekânının yönlenme ve manzara özellikleri zamanının çoğunu bu mekânda geçiren yaşlı kullanıcılar için önemlidir. Yașama mekânları yaşlı kullanıcıların dışarıyı izleyebilmeleri için geniş ve büyük pencerelere sahip olmalıdır. Pencere önlerinde kullanıcıların dışarıyı izlerken oturacakları rahat bir koltuk yer almalıdır. Yașama mekânının sokağa ya da caddeye bakması kullanıcıların gün içerisinde dışarıdaki yaşam ile ilişkilerini güçlendirmektedir (WHO, 2007; Burton, Mitchell \& Stride, 2015; Hadjri, Morris, Akintoye, Buffin, Gadakari, Bola \& Wang, 2018; Park \& Porteus, 2019).

\section{MATERYAL VE YÖNTEM}

$\mathrm{Bu}$ çalıșmada yerinde yașlanmada konut iç mekân düzenlemesine yönelik tasarım prensipleri ve donatı özelliklerini ortaya koymayı amaçlayan yüksek lisans tez çalışması kapsamında yapılan alan çalıșmasından elde edilen verilerin yalnızca bir bölümü ele alınmaktadır. Çalışma temel olarak beş adımda gerçekleștirilmiştir (Şekil 1).

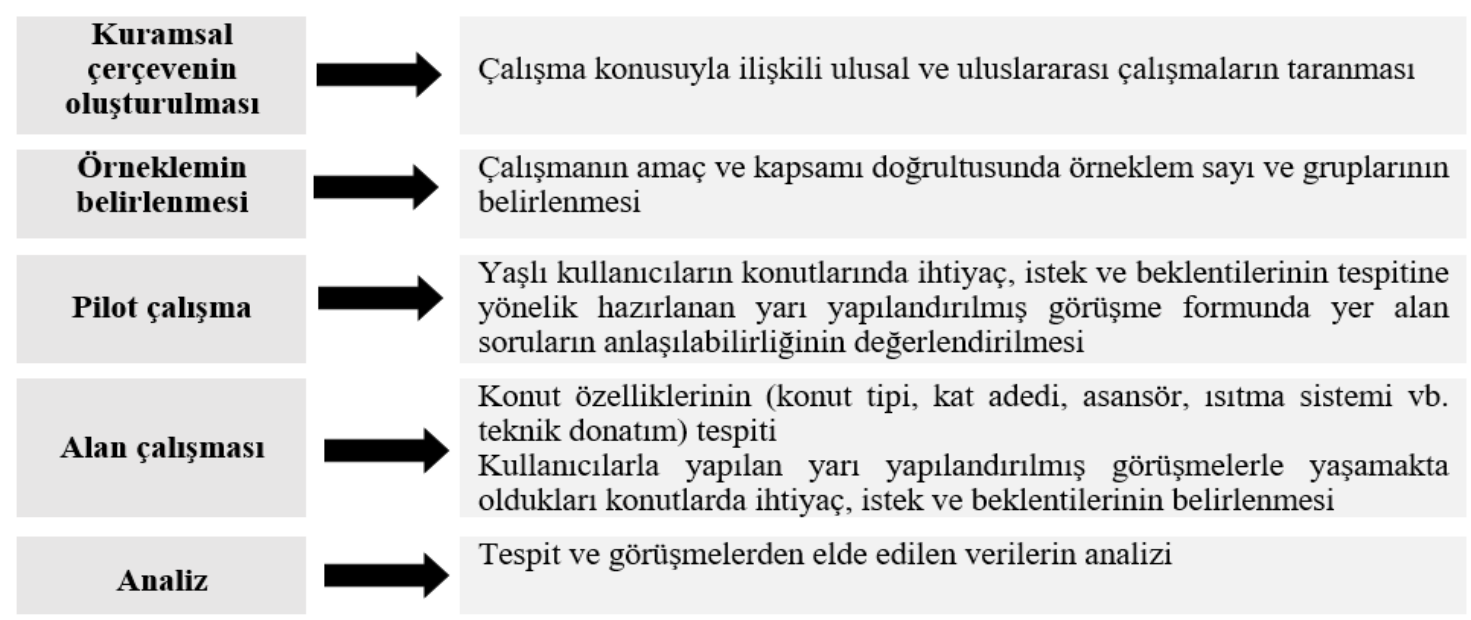

Şekil 1. Deneysel çalışmanın adımları

Çalıșmanın ilk adımında, yașlılık, yașlanma, barınma modelleri, aktif ve kaliteli yaşlanma ve yerinde yaşlanma kavramları ile ilgili yerli ve yabancı literatür taranarak kuramsal çerçeve oluşturulmuştur.

İkinci adımda çalışma örneklemi ve sayısı belirlenmiştir. Çalışma örneklemi Trabzon ili Ortahisar ilçesinde yaşayan konutlarında kendi ihtiyacını kendi görebilen, konutlarında yalnız ya da sadece eşi ile yaşamını sürdüren, zihinsel herhangi bir sağllk problemi bulunmayan, sağlıklı iletişim kurma becerisine sahip olan ve en az 10 yıldır aynı konutta yașamını devam ettiren 65 yaș ve üstü yașlı kullanıcılardır. Çalışmanın istatiksel olarak sağlıklı ve güvenilir sonuçlar verebilmesi için örneklem sayısı belirlenirken TUIK' ten alınan veriler doğrultusunda örneklem sayısı \% 90 güvenilirlik ve $\% 10$ hata payı gözetilerek hesaplanmıştır. Bu kapsamda Trabzon ili Ortahisar ilçesinde yașamakta olan 65 yaș ve üstü bireylerin sayısına bağlı olarak 65-74 yaş aralığından 42 kişi, 75-84 yaş aralığından 20 kişi, 85 ve üzeri yaş grubundan 8 kişi olmak üzere toplam 70 yaşlı kullanıcı belirlenmiştir. Başlangıçta çalışmaya katkı sağlayabileceği ve yeterli düzeyde cevap alınabileceği düşünülen bir yaşlı kullanıcı belirlenerek ardından kartopu tekniği ile yeni yaşlı kullanıcılara ulaşılmıştır olup toplamda 70 yaşlı kullanıcı ile görüşme yapılmıştır.

Çalışmanın üçüncü adımında, kullanıcıların konuttaki ihtiyaç, istek ve beklentilerine ilişkin hazırlanan yarı yapılandırılmış görüşme sorularının yaşlı kullanıcılar tarafından anlașılıp anlaşılamadığı tespit etmek amacıyla 10 yaşlı kullanıcı ile yarı yapılandırılmıș 
görüşmeler gerçekleştirilerek bir pilot çalışma yapılmıștır. Çalışmanın dördüncü adımında, pilot çalışmadan elde edilen veriler ışığında alan çalışmasında sorulacak sorulara yönelik gerekli revizyonlar yapılarak bir alan çalışması gerçekleştirilmiştir. Alan çalışmasında belirlenen 70 yaşlı kullanıcı ile yarı yapılandırılmış görüşmeler yapılmıştır. Yarı yapılandırılmış görüşmeler önceden alınan randevular doğrultusunda yaşlı kullanıcıların konutlarına gidilerek birebir ve yüz yüze șeklinde gerçekleştirilmiştir. Yapı yapılandırılmış görüşme süresi her bir kullanıcı ile yaklaşık 50 dakika sürmüştür. Yarı yapılandırılmış görüşmelerde önceden hazırlanan açık ve kapı uçlu sorular kullanıcılara yöneltilmiștir. Yapılan görüşmeler ses kaydına alınarak görüşme sonrasında yeniden dinlenerek yanıtlar görüşme formlarına ișlenmiștir. Görüşme formunda yer alan sorular kullanıcı profili, barınma tercihleri, mevcut konutlarına ve hayallerindeki konutlara ilişkin sorular olmak üzere 4 başlıkta toplanmıștır. Kullanıcı profiline iliş̧in sorularda kullanıcıların demografik verilerinin ve konut kullanım sürelerinin tespitine ilişkin sorular yer almaktadır. Barınma tercihlerine ilişkin kullanıcıların yaşlllık dönemini nerede geçirmek istediklerine dair tercileri ve neden faktörlerine ilişkin sorular sorulmuştur. Mevcut konut kullanımlarına ilișkin sorularda hangi eylemleri gerçekleştirdikleri, sevdikleri ve rahatsız oldukları özellikler, hayallerindeki konuta ilișkin sorularda ise nasıl bir konutta yaşamak istediklerine dair sorular yer almaktadır. Yapı yapılandırılmış görüşmelerin yanı sıra kullanıcıların yaşadıkları konuta ilişkin tespitler yapılarak kullanıcılardan alınan izinler doğrultusunda konutlar fotoğraflanmıştır. Çalışmanın beşinci adımında ise açık uçlu sorulara verilerin yanıtların gruplanarak SPSS istatistiki analiz programında genel frekans dağılımları hesaplanmış ve veriler tablolaştırılarak analiz edilmiștir. Kullanıcıların yarı yapılandırılmıș görüşmelerde açık uçlu sorulara birden fazla cevap vermelerinden dolayı yanıtların ağırlıklı olarak saptanması yerine kendi içlerindeki ağırlıkları toplamı görüşmeci sayısına (70) oranlanmiștır.

\section{BULGULAR VE TARTIŞMA}

Yaşlı kullanıcılar ile yapılan yarı yapılandırılmıș görüşmelerden elde edilen veriler SPSS istatistik programında analiz edilerek genel frekans dağılımları hesaplanmıștır. Bu çalıșmada; yașlı kullanıcıların demografik özelliklerine, kullanıcıların barınma tercihleri ve nedenlerine, yaşama mekânında hangi eylemleri gerçekleştirdiğine, yaşama mekânlarının sevdikleri ve sevmediklerine özelliklerine ve hayallerinde nasıl bir yaşama mekânı istediklerine ilişkin sorulara ilișkin cevaplardan elde edilen verilere yer verilmiştir. Görüşmeye katılan kullanıcıları profili ile ilgili elde edilen verilere bakıldığı yaşlı kullanıcıların \%60'ı 65-74 yaş aralığında, \%28,6'sı 75-84 yaș aralığında, \%11,4'ü ise 85 yaș ve üzeridir. Katılımcıların \%67,1'i kadın, \%32,9'u ise erkeklerden oluşmaktadır. Medeni durumlarına bakıldığına \%80'i evli, \%20'si ise dul ya da eşinden ayrılmıştır. Yaşlı kullanıcıların \%10'u ilkokul, \%18,6's ortaokul, $\% 48,6$ 'sı lise, $\% 21,4$ 'ü üniversite ve \% 1,4'ü ise lisansüstü mezunudur. Kullanıcıların meslek dağılımlarına bakıldığında \% 40'ı ev hanımı, \% 37,1'i devlet memuru, \%22,9'u ise özel sektör olduğu görülmektedir. Çalıșma durumları ile ilgili olarak yaşlı kullanıcıların \% 55,7'i emekli, \% 40'ı halen çalışmakta, $\%$ 4,3'ü ise aktif olarak çalıșmamaktadır. Görüșmeye katılan yaşlı kullanıcıların \%41'i 25 ve üzeri yıldır, \%18,6'sı 20-24 yıl, \%21,4'ü 15-19 yıldır, \%18,6'sı ise 10-14 yıldır aynı konutta yaşamaktadır (Tablo 1 ).

Tablo 1. Kullanıcı profili

\begin{tabular}{llc}
\hline $\begin{array}{l}\text { Kullanıcı } \\
\text { Profili }\end{array}$ & Grup & Yüzde (\%) \\
\hline Yaş & 65-74 & 60,0 \\
& $75-84$ & 28,6 \\
& 85 ve üzeri & 11,4 \\
Cinsiyet & Kadın & 67,1 \\
& Erkek & 32,9 \\
Medeni & Evli & 80,0 \\
durum & Dul/Eşinden & 20,0 \\
& Ayrılmış & \\
Eğitim & İlkokul & 10,0 \\
durumu & Ortaokul & 18,6 \\
& Lise & 48,6 \\
& Üniversite & 21,4 \\
& Lisansüstü & 1,4 \\
Meslek & Ev hanımı & 40,0 \\
& Devlet memuru & 37,1 \\
& Özel sektör & 22,9 \\
Çalışma & Emekli & 55,7 \\
durumu & Çalışıor & 40,0 \\
& Çalışmıyor & 4,3 \\
Mevcut & 25 ve üzeri yıl & 41,0 \\
konutlarını & 20-24 yıl & 18,6 \\
kullanma & 15-19 yl & 21,4 \\
süreleri & 10-14 yıl & 18,6 \\
\hline & & \\
\hline
\end{tabular}

Yaşlı kullanıcılara yaşlılık döneminde yaşamlarını nerede geçirmek istedikleri sorulduğunda kullanıcıların \%97,1'lik çok büyük bir çoğunluğu kendi evinde yani yerinde yașlanmak istemiștir. Kullanıcıların \%2,9'u bakım evini tercih ederken, yaşlılar için tasarlanan yeni konut sitelerinde ve çocuğunun yanında yaşamak isteyen olmamıștır (Tablo 2). Yaşlı kullanıcılar kendi evlerini yașamak isteme nedenleri ile ilgili olarak \%65,7 gibi çok büyük bir çoğunluğu "Insanın kendi evi gibisi yok", "Başka yerde rahat edemem", "Kimseye yük olmak istemem" șeklinde ifadeler kullanarak kendi evlerinde rahat, özgür ve bașkasına yük olmama duygusunu vurgulamıștır. Kullanıcıların barınma tercihlerine ilişsin nedenlerinde \%21,4'ü mutluluk ve huzurun, $\% 17,1$ 'i aidiyet duygusunun, $\% 10$ 'u ise komşuluk ve sosyal ilișkilerin etkili olduğuna vurgu yapmıștır. 
Tablo 2. Kullanıcıların barınma tercihleri ve nedenleri

\begin{tabular}{|c|c|c|}
\hline $\begin{array}{l}\text { Kullanici } \\
\text { Tercihleri }\end{array}$ & Grup & $\begin{array}{c}\text { Yüzde } \\
(\%)\end{array}$ \\
\hline \multirow{4}{*}{$\begin{array}{l}\text { Yaşlı } \\
\text { kullanıcıların } \\
\text { yaşamak } \\
\text { istedikleri yere } \\
\text { dair tercihleri }\end{array}$} & Kendi evi & 97,1 \\
\hline & Bakım evi & 2,9 \\
\hline & $\begin{array}{l}\text { Yaşlılar için tasarlanana } \\
\text { yeni konut siteleri }\end{array}$ & 0,0 \\
\hline & Çocuğunun yanı & 0,0 \\
\hline \multirow{4}{*}{$\begin{array}{l}\text { Yaşlı } \\
\text { kullanıcıların } \\
\text { yaşamak } \\
\text { istedikleri yer } \\
\text { tercihlerinin } \\
\text { gerekçeleri }\end{array}$} & $\begin{array}{l}\text { Rahatlık, özgürlük ve } \\
\text { bașkasına yük olmama } \\
\text { duygusu }\end{array}$ & 65,7 \\
\hline & $\begin{array}{l}\text { Mutlu ve huzurlu } \\
\text { hissetme }\end{array}$ & 21,4 \\
\hline & $\begin{array}{l}\text { Geçmiş ile bağ ve } \\
\text { alıșkanlık }\end{array}$ & 17,1 \\
\hline & $\begin{array}{l}\text { Komşuluk ilişkisi ve } \\
\text { sosyal olma }\end{array}$ & 10,0 \\
\hline
\end{tabular}

Yaşlı kullanıcılar yaşama mekânlarında neler yaptıkları, bu mekânı hangi amaçlarla kullandıkları sorulduğunda, genellikle oturma-dinlenme (\%100), misafir ağırlama $(\% 98,6)$, televizyon izleme $(\% 95,7)$, yemek yeme $(\% 85,7)$ eylemlerini gerçekleștirdiklerini belirtmişlerdir. Kullanıcıların yaşama mekânında gerçekleștirilen temel eylemlerin yanı sıra diğer olarak ifade ettikleri el işi yapma, çini boyama, bulmaca çözme gibi hobi aktiviteleri $(\% 65,7)$ gerçekleştirmektedir. Ayrıca yaşlı kullanıcıların bir kısmı(\%10) yaşama mekânında yatma-uyuma eylemlerini de gerçekleştirmektedirler (Tablo 3).

Tablo 3. Yaşama mekânında gerçekleștirilen eylemler

\begin{tabular}{llc}
\hline Kullanıcı Tercihleri & Grup & $\begin{array}{c}\text { Yüzde } \\
(\%)\end{array}$ \\
\hline & Oturma- & 100,0 \\
Yaşama mekânında & Dinlenme & \\
gerçekleştirdikleri & A & 98,6 \\
eylemlirlama & \\
& Tv İzleme & 95,7 \\
& Yemek Yeme & 85,7 \\
& Diğer & 65,7 \\
& Yatma- Uyuma & 10 \\
\hline
\end{tabular}

Yaşlı kullanıcılar yaşama mekânlarının en sevdikleri özellikleri sorulduğunda \%32,9'u mekân büyüklüğü ve yerleșimi, \%27,1'i mobilya ve aksesuarlara ilișkin pozitif özellikleri (rahat koltuklar, koltuğun yumuşaklığı, mobilyaların hafifliği vb.), \%20'si yönlenme ve manzara, \%20'si gün ışığını öncelikli olarak ifade etmiştir. Bunların yanı sıra yaşlı kullanıcıların \%11,4'ü konut içi konumuna ve \%10’u anı değeri olan mobilya ve aksesuarlara vurgu yapmıştır (Tablo 4).
Tablo 4. Kullanıcıların yaşama mekânında en sevdikleri özellikler

\begin{tabular}{|c|c|c|}
\hline $\begin{array}{l}\text { Kullanıcı } \\
\text { Tercihleri }\end{array}$ & Grup & $\begin{array}{l}\text { Yüzde } \\
(\%)\end{array}$ \\
\hline \multirow{10}{*}{$\begin{array}{l}\text { Yaşlı } \\
\text { kullanıcıların } \\
\text { yaşama } \\
\text { mekânlarında } \\
\text { en sevdikleri } \\
\text { özellikler }\end{array}$} & $\begin{array}{l}\text { Mekân Büyük Oluşu ve } \\
\text { Yerleşimi }\end{array}$ & 32,9 \\
\hline & Mobilya ve Aksesuara & \multirow[t]{2}{*}{27,1} \\
\hline & İlişkin Pozitif Özellikler & \\
\hline & Yönlenme ve Manzara & 20,0 \\
\hline & Gün Ișığına İlișkin & \multirow[t]{2}{*}{20,0} \\
\hline & Pozitif Özellikler & \\
\hline & Konut İçi Konum & 11,4 \\
\hline & Yarı Açık Mekân & \multirow[t]{2}{*}{10,0} \\
\hline & Kullanımı & \\
\hline & $\begin{array}{l}\text { Anı Değeri Olan Mobilya } \\
\text { ve Aksesuar }\end{array}$ & 10,0 \\
\hline
\end{tabular}

Yaşlı kullanıcılar yaşama mekânlarında rahatsız oldukları hususlar sorulduğunda \%41,4'ü mekânın küçük oluşu ve yerleșimini, \%20'si mobilya ve aksesuara ilișkin negatif özellikleri (rahatsız koltuklar, ağır mobilyalar vb.) dile getirmiștir. Bunların yanı sıra yaşlı kullanıcıların \%12,9'u isıl konfor koşulları, \%7,1'i konut içi konumu, \%7,1'i yarı açı mekân kullanımı ve \%2,9'u yönlenme ve manzaraya dair negatif özellikleri belirtmiştir (Tablo 5).

Tablo 5. Kullanıcıların yaşama mekânında rahatsız oldukları özellikler

\begin{tabular}{llc}
\hline Kullanıcı Tercihleri & Grup & $\begin{array}{c}\text { Yüzde } \\
\text { (\%) }\end{array}$ \\
\hline & $\begin{array}{l}\text { Mekân Küçük } \\
\text { Oluşu ve Yerleşimi }\end{array}$ & 41,4 \\
Yaşlı kullanıcıların & Mobilya ve & 20,0 \\
yaşama & Aksesuara İlişkin & \\
mekânlarında & Negatif Özellikler & \\
rahatsız oldukları & Isıl Konfor & 12,9 \\
özellikler & Gün Işı̆ı̆ının & 11,4 \\
& Yetersizliği & \\
& Konut İçi Konum & 7,1 \\
& Yarı Açı Mekân & 7,1 \\
& Kullanımı & \\
& Yönlenme ve & 2,9 \\
& Manzara & \\
\hline
\end{tabular}

Kullanıcılarına hayallerindeki yașama mekânının nasıl olduğu sorulduğunda yaşlı kullanıcıların \%64,3'ü mekânın büyüklüğü ve yerleşim özellikleri, \%44,3'ü mekânın manzarası, baktığı yön, \%35,7'si mobilya ve aksesuara ilişkin özelliklere (geniş, kolçaklı ve rahat koltuklar vb.) vurgu yapmıștır. Bunların yanı sıra kullanıcıların \%21,4'ü yarı açık mekân kullanımını, \%18,6'sı yaşama mekânının mutfak ile bir arada çözümüne, \%11,4'ü estetik faktörlere, \%10'u ise el işi/okuma/çalışma/müzik köşesi gibi bir özel eylem alanı istediklerini belirtmiștir (Tablo 6). 
Tablo 6. Kullanıcıların hayallerindeki yaşama mekânına ilișkin özellikler

\begin{tabular}{llc}
\hline Kullanıcı Tercihleri & Grup & $\begin{array}{c}\text { Yüzde } \\
\%\end{array}$ \\
\hline & Mekân Büyüklüğü & 64,3 \\
& ve Yerleşimi & \\
Yaşlı kullanıcıların & Gün ışığı & 44,3 \\
hayallerindeki & Yönlenme ve & 40 \\
yașama mekânına & Manzara & \\
ilişkin özellikler & Mobilya ve & 35,7 \\
& Aksesuara İlişkin & \\
& Pozitif Özellikler & \\
& Yarı Açı Mekân & 21,4 \\
& Kullanımı & \\
& Yaşama Mekânı ve & 18,6 \\
& Mutfağın Tek & \\
& Hacimde & \\
Çözülmesi & 11,4 \\
& Estetik Faktörler & 10,0 \\
\hline
\end{tabular}

Yaşlı kullanıcılar ile yapılan yarı yapılandırılmış görüşmelerde kendi yaşama mekânlarında sevdikleri, rahatsız oldukları özellikler ile sahip olmak istedikleri yaşama mekânın özellikleri tablolaștırılarak veriler birlikte irdelenmiştir (Tablo 7). Kullanıcıların üç soruya verdikleri yanıtlar karşılaştırıldığında mekân büyüklüğü ve yerleşimi her durumda en öne çlkan özellik olmuştur. Sıralamaları değişmek ile birlikte mobilya ve aksesuar özellikleri, yönlenme ve manzara, gün ışı̆̆ı ve yarı açık mekân kullanımı yaşlı kullanıcıların yaşama mekânı ile ilgili her soruda vurguladı ̆̆ diğer konular olmuştur. Bunların yanı sıra kullanıcıların konutlarındaki yașama mekânlarına dair dile getirmedikleri ancak hayallerindeki yașama mekânında olmasını istedikleri özel eylem alanı ihtiyacl, estetik faktörler ve yaşama mekânının mutfak ile birlikte çözümü önemsedikleri konulardandır. Karşılaştırma tablosuna genel olarak bakıldığında yaşlı kullanıcıların konutlarında şikâyetçi oldukları hususlar ile sahip olmak istedikleri yaşama mekânına ilişkin özellikler tutarlık göstermektedir.

Tablo 7. Kullanıcıların konut yaşama mekânında sevdikleri ve rahatsız oldukları özellikleri ile hayallerindeki yaşama mekânı arasındaki ilișki

\begin{tabular}{|c|c|c|c|c|c|}
\hline $\begin{array}{l}\text { Yaşama Mekânında } \\
\text { Sevilen özellikler }\end{array}$ & $\begin{array}{c}\text { Yüzde } \\
\%\end{array}$ & $\begin{array}{l}\text { Yaşama Mekânında } \\
\text { Rahatsız olunan } \\
\text { Özellikler }\end{array}$ & Yüzde \% & $\begin{array}{l}\text { Hayallerindeki Yaşama } \\
\text { Mekânına İlişkin } \\
\text { Özellikler }\end{array}$ & $\begin{array}{c}\text { Yüzde } \\
\%\end{array}$ \\
\hline $\begin{array}{l}\text { Mekân büyük oluşu ve } \\
\text { yerleşimi }\end{array}$ & 32,9 & $\begin{array}{l}\text { Mekân küçük oluşu ve } \\
\text { yerleşimi }\end{array}$ & 41,4 & $\begin{array}{l}\text { Mekân büyük oluşu ve } \\
\text { yerleşimi }\end{array}$ & 64,3 \\
\hline $\begin{array}{l}\text { Mobilya ve aksesuara } \\
\text { ilișkin pozitif özellikler }\end{array}$ & 27,1 & $\begin{array}{l}\text { Mobilya ve aksesuara } \\
\text { ilișkin negatif özellikler }\end{array}$ & 20,0 & $\begin{array}{l}\text { Gün ışığına ilişkin pozitif } \\
\text { özellikler }\end{array}$ & 44,3 \\
\hline Yönlenme ve manzara & 20,0 & Isıl konfor & 12,9 & Yönlenme ve manzara & 40,0 \\
\hline $\begin{array}{l}\text { Gün ışığına ilişkin pozitif } \\
\text { özellikler }\end{array}$ & 20,0 & Gün ışığının yetersizliği & 11,4 & $\begin{array}{l}\text { Mobilya ve aksesuara } \\
\text { ilișkin pozitif özellikler }\end{array}$ & 35,7 \\
\hline Konut içi konum & 11,4 & Konut içi konum & 7,1 & $\begin{array}{l}\text { Yarı açılk mekân } \\
\text { kullanımı }\end{array}$ & 21,4 \\
\hline $\begin{array}{l}\text { Yarı açık mekân } \\
\text { kullanımı }\end{array}$ & 10,0 & $\begin{array}{l}\text { Yarı açık mekân } \\
\text { kullanımı }\end{array}$ & 7,1 & $\begin{array}{l}\text { Salon ve mutfağın tek } \\
\text { hacimde çözülmesi }\end{array}$ & 18,6 \\
\hline \multirow{2}{*}{$\begin{array}{l}\text { Anı değeri olan mobilya } \\
\text { ve aksesuar }\end{array}$} & 10,0 & Yönlenme ve manzara & 2,9 & Estetik faktörler & 11,4 \\
\hline & & & & Özel eylem alanı & 10,0 \\
\hline
\end{tabular}

Yașlı kullanıcılar gün içerisinde yașama mekânında uzun süre vakit geçirdikleri için mekânın büyüklüğünü ve örgütlenme karakterini oldukça önemsemektedirler. Gerçekleștirilen görüşmelerde kullanıcılar mekânın büyüklük ve örgütlenme karakteri ile ilgili olarak "Geniș ve ferah olması", "Rahat bir șekilde yürüyüp hareket edebileceğim kadar büyük" ifadeleri ile pozitif özelliklerine, "Yürürken sürekli bir șeylere (essyalara) çarpıyorum", "Cok küçük ve sıkışık bana yetmiyor" ifadeleri ile negatif özelliklerine vurgu yapmıştır (Tablo 8). Kullanıcıların rahatsızlıklarının nedeni yașın artmasına bağlı olarak yaşlılık döneminde ortaya çıkan hareket kısıtlılıklarıdır. Yaşama mekânının yaşlı kullanıcıların ihtiyaç ve isteklerini karşılayacak yeterli büyüklüğe sahip olmaması şikayetçi olmalarında oldukça etkili olmuştur. Kullanıcılar donatı organizasyonunun yanı sıra mekanda yer alan mobilya ve aksesuar yoğunluğuna da vurgulayarak günlük aktiviteleri için daha çok sirkülasyon alanına sahip olma isteklerini dile getirmișlerdir. Kullanıcılar hayallerindeki yaşama mekânı ile ilgili mevcut yașama mekânlarının pozitif özellikleri ile benzer yanıtlar vermiştir.

Yaşama mekânında yaşlı kullanıcılar için öne çıkan bir diğer konu mobilya ve aksesuara ilișkin olumlu ve olumsuz özelliklerdir. Kullanıcılar "Koltuğumun olması", "İlaç ve gözlüklerim için bir sehpanın olması", "Açık renkli eşyalarımın olması", "Televizyonum olmazsa olmazım ses oluyor bana" gibi ifadeler ile pozitif özelliklerine, "Koltuğumun olmaması", "Koltuklarımın koyu olması içime kasvet veriyor" gibi ifadeler ile negatif özelliklerine vurgu yapmıștır (Tablo 8). Yaşama mekânında eylemlerini gerçekleştirebilmeleri için ihtiyaç duydukları mobilyaların varlığı-yokluğu onlar için önemlidir. Bunun yanı sıra mobilyaların renk, desen gibi estetik özelliklerinin de yaşlı kullanıcılar için önemli olduğu görülmektedir. 
Kullanıcılar mobilyaların form ve boyutsal özellikleri ile ilgili olarak "Yatıp uzanabileceğim kadar büyük ve geniş koltuklar", "Mobilyaların hafif ve istediğimde kolaylıkla kaldırıp tașiyabiliyorum", "Kollu (kolçaklı) koltukların olması" şeklinde ifadeler ile pozitif özelliklerine, "Koltuğum rahatsiz olması", "Koltuklarım çok yumuşak oturunca içine çöküyorum" gibi ifadeler ile negatif özellikleri dile getirilmiștir (Tablo 8). Bunun nedeni mobilyaların formlarının yaşlı kullanıcıların antropometrik ölçülerine uygun tasarlanmamış olmasıdır. Ayrıca kullanıcılar yaşlılık dönemlerinde kaldırma, çekme, taşıma gibi eylemleri kaslarının zayıflaması ve güç kayıpları nedeni ile gerçekleştirmede zorluk yaşamaktadır. Bu sebeple mobilyaların hafif olması kullanıcılar tarafından oldukça önemsenmektedir.

Yaşama mekânının yönlenme ve manzarası gündelik yaşamlarının büyük bir bölümünü konutlarının yaşama mekânlarında geçiren yaşlı kullanıcılar için öne çıkan bir diğer konudur. Yaşlı kullanıcılar konutlarında yaşlılık döneminde genellikle yalnız ya da eşleri ile birlikte yaşadıkları ve hareket kısıtlılıklarından ötürü dışarıya oldukça nadir çıkabilmeleridir. Bu sebeple yaşlı kullanıcılar yaşama mekânlarının sokağa, caddeye ya da yeșil bir alana bakmasını istemektedir. Çünkü sıkıldıklarında pencereden dışarıyı seyretmenin onlar için önemli olduğunu böylece sıkılmadıklarını vurgulamıșlardır. $\mathrm{Bu}$ tür aktiviteler sayesinde yaşlı kullanıcılar hem kendilerini daha mutlu ve pozitif hissetmekte hem de toplumdan izole olmadıklarını vurgulamışlardır. Kullanıcılar hayallerindeki yaşama mekânının yönlenme ve manzarasına ilișkin sevdikleri özellikler ile tutarlılık gösteren benzer yanıtlar vermiştir.

Yaşlı kullanıcıların yaşama mekânlarında gün ıșığı önemsedikleri başka bir özelliktir. Kullanıcılar gün ışığı için "Benim için güneș demek sağlık demek", "Güneş odadaki tüm negatif enerjiyi alıyor" gibi ifadeler ile gün ışığının hayatlarındaki önemini vurgulamıșlardır (Tablo 8). Bunun nedeni gün ıșığı ile yaşlı kullanıcıların kendilerini daha pozitif ve daha sıcak hissediyor olmalarıdır.

Kullanıcılar ayrıca mevcut ve hayallerindeki yașama mekânlarına ilişkin olarak yarı açı mekân kullanımı, konut içi konum, anı değeri olan mobilya ve aksesuar kullanımları, yașama mekânı ile mutfağın bir arada çözümü, estetik faktörler ve özel eylem alanlarına da değinmişlerdir.

Tablo 8. Yaşlı kullanıcıların yaşama mekânlarından genel görünümler

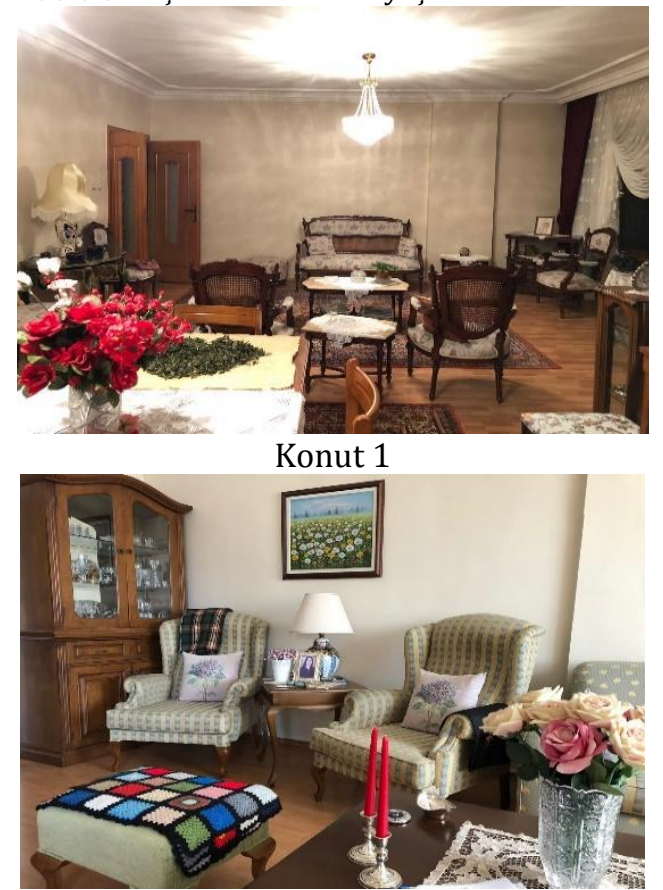

Konut 15

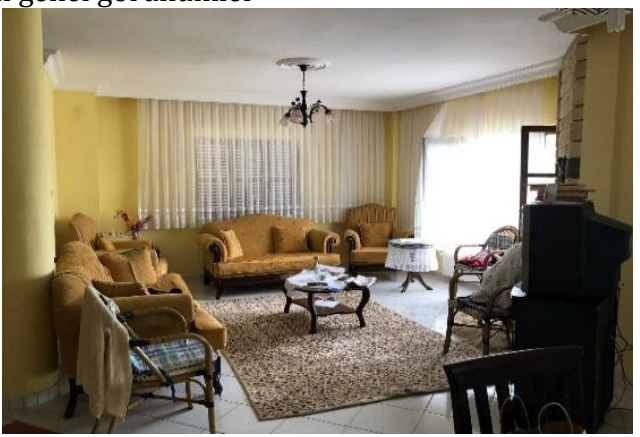

Konut 2

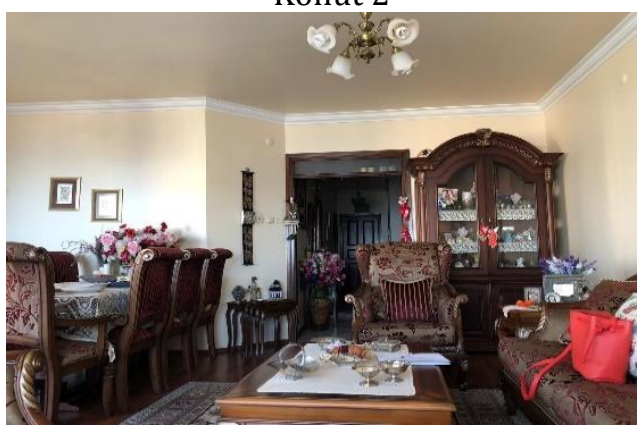

Konut 32

\section{SONUÇ VE ÖNERÍLER}

Yaşlılık döneminde çeşitli kayıplarına bağlı olarak yaşam alanı sınırlanan yaşlı kullanıcıların yaşamlarının büyük bir bölümü konutlarında geçmektedir. Özellikle konutlarında en çok vakit geçirdikleri yaşama mekânlarının tasarımlarının kullanıcıların ihtiyaçlarına ve isteklerine uygun tasarlanmış olması onların kendi kendilerine yetebilmelerini uzatmalarında yaşam kalitelerini arttırmada ve bir başkasına ihtiyaç duymadan alışkın oldukları kendi evlerinde yani yerinde yaşlanabilmelerinde önemlidir. Yaşamlarını sürdürdükleri mevcut konut yașama mekânlarının yaşlı kullanıcıların ihtiyaçlarını karşılamaması ve onlara uygun tasarlanmamış olması kullanıcıların mekân içerisindeki hareketlerini kısıtlayarak günlük aktivitelerini gerçekleştirmelerini zorlaştırmaktadır. Bu nedenle gerek mevcut konut yașama mekânlarının tadilatlarında gerekse yaşlılara yönelik yeni yapılacak konutların yaşama mekânlarının tasarımlarında kullanıcıların gereksinim ve isteklerinin doğru bir şekilde belirlenmesi oldukça önem taşımaktadır. Tespit edilen ihtiyaç ve istekler doğrultusunda 
mekânların düzenlenmesi ya da yeniden tasarlanması yaşlı kullanıcıların yaşam memnuniyetlerini olumlu yönde etkileyecektir. Konut yaşama mekânlarının tasarım prensipleri iç mekân özellikleri, mekânın konuttaki diğer mekânlar ile ilişkisi ve yaşama mekânının dış mekân ile ilişkisi olarak üç başlıkla sıralanabilir.

Tablo 8 (devam). Yaşlı kullanıcıların yaşama mekânlarından genel görünümler

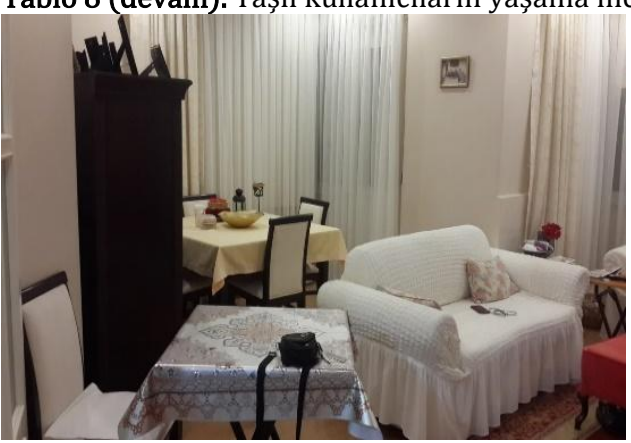

Konut 8

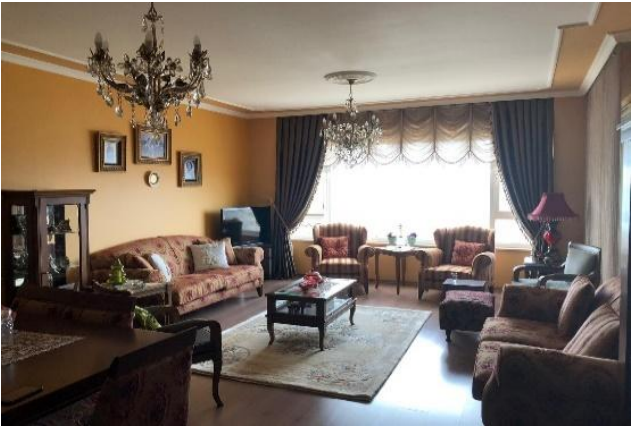

Konut 17

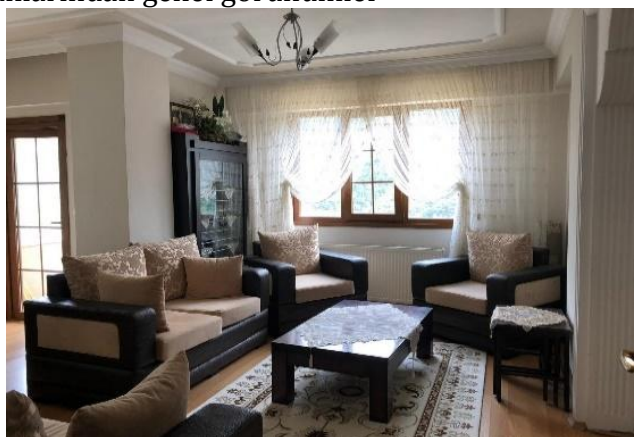

Konut 12

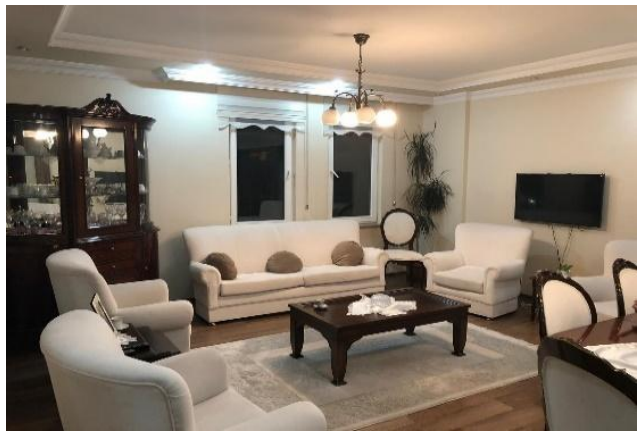

Konut 26
Yașama mekânlarının iç mekân özellikleri mekân organizasyonu, donatı, malzeme, yapısal detay çözümleri ve fiziksel konfor koşulları ile ilişkilidir. Yaşama mekânı, mekân içerisinde gerçekleștirilecek eylemler göz önünde bulundurularak yeterli büyüklükte ve rahatlıkla kullanıma imkân verecek şekilde örgütlenmelidir. Kullanıcıların mekân içerisinde hobi ve uğraşlarına yönelik özel bir eylem alanı tasarlanmalıdır. Mekânın yaşlı kullanıcılara kullanımına uygun şekilde örgütlenmesi ve yeterli sayıda donatı kullanımı kullanıcıların mekânda kolay sirküle olmalarını sağlayarak herhangi bir problem yaşamadan günlük yaşam aktivitelerini gerçekleştirmeleri imkân verecektir. Donatıların form ve boyutsal özellikleri kullanıcıların fiziksel özelliklerine ve antropometrik boyutlarına uygun tasarlanmış olmalıdır. Yaşlı kullanıcılara yönelik tasarlanan donatı ve mobilyalar kullanıcıların eylemlerini kolaylıkla gerçekleștirmelerini sağlayarak bir başkasına ihtiyaç duymadan yaşantılarını devam etmelerini destekleyecektir. Malzeme seçimleri mekânda yașanabilecek kaza risklerini en aza indirecek ve kullanıcıların sağlıklarını olumsuz yönde etkilemeyecek özelliklerde tercih edilmelidir. Mekânda yer alan pencere ve kapı gibi mimari detaylar kullanıcıların kullanımına uygun nitelik ve ölçülere sahip olmalıdır. Fiziksel konfor koşulları yaşlı kullanıcıların mekân içerisindeki eylemlerini gerçekleștirmelerini kolaylaștırmaktadır. Gün ıșığı görsel konforu sağlamanın yanı sıra kullanıcılar üzerinde fiziksel ve ruhsal sağlıkları üzerinde etkilidir.
Yaşama mekânlarının yarı açı mekân yaşlı kullanıcıların yașam kalitelerini ve yașam memnuniyet düzeylerini arttırmaktadır. Özellikle yaşama mekânları doğrudan yarı açık mekân ile ilişkili tasarlanmalıdır. Yarı açık mekânlar yaşlı kullanıcıların toplumdan izole olmadan aktif bir yaşam sürdürmelerini desteklemektedir. Konut yașama mekânlarının yönlenme ve manzara özellikleri kullanıcıların dış mekân ile ilişki kurması açısından önem taşımaktadır. Yaşama mekânlarının sokağa, caddeye ya da bahçeye bakması kullanıcıların konut dışındaki yaşamdan soyutlanmadan yaşamlarını devam ettirmeleri için gereklidir.

Yaşama mekânları konutun en dışa açık mekânı olduğu için olabildiğince girişe yakın konumlandırılmalıdır. Yașama mekânları konut içerisinde özellikle yarı açık mekânlar ile doğrudan ilişskili olmalıdır. Yarı açık mekânlar konutlarında tek başına yaşamlarını sürdüren kullanıcıların dışarı ile iletișim kurdukları mekânlardır. Bu mekânlar kullanıcıların toplumdan izole olmadan, aktif bir yaşam sürdürmelerini desteklemekte ve yaşam memnuniyetlerini arttırmaktadır. Yarı açık mekânın yanı sıra yașama mekânlarının mutfak ile birlikte çözülmesi hem daha ferah bir atmosfer yaratmakta hem de kullanıcıların bir yandan ișlerini yaparken diğer yandan misafirleri ile iletişimlerini devam ettirmelerini sağlayabilecektir.

Çıkar Çatışması

Yazarların herhangi bir çıkara dayalı ilişkisi yoktur. 


\section{Araştırma Desteği}

Bu çalışma Karadeniz Teknik Üniversitesi Bilimsel Araştırma Projeleri Birimi tarafından desteklenmiştir. Proje numarasi: FYL-2020- 8518.

\section{Etik Kurul Onamı}

Karadeniz Teknik Üniversitesi Fen ve Mühendislik Bilimleri Etik Kurulu'ndan (Tarih: 17.05.2021, Oturum no: 14, Karar no: E-26014373-050.01.04128890) onay alınmıştır.

Teşekkür

Araştırmaya destek veren Karadeniz Teknik Üniversitesi Bilimsel Araştırma Projeleri Birimine teșekkür ederiz.

\section{KAYNAKC A}

Aksoy, A. D., \& Günay, G. (2017). Yaşlıların barınma ihtiyacına alternatif olarak sürdürülebilir yașlı köyleri. Düzce Üniversitesi Sosyal Bilimler Enstitüsü Dergisi, 7(2), 1-19.

Anonim, (2005). Check for safety: a home fall prevention checklist for older adults, centers for disease control and prevention national center for injury prevention and control. https://www.cdc.gov/steadi/pdf/check for sa fety_brochure-a.pdf Erişim Tarihi: 08.05.2020.

Anonim, (2016). Aging in place design guidelines for independent living in multifamily buildings, enterprise green communities. https://www .enterprisecommunity. org/resources/agingplace-design-guidelines-18245. Erişim Tarihi: 08.05.2020.

Anonim (2021). Aging in place remodelling checklist, https://www.nahb.org/education-andevents/education/designations/CertifiedAging-in-Place-Specialist-CAPS/AdditionalResources/Aging-In-Place-RemodelingChecklist. Erişim Tarihi: 12.01.2021

Bakker, R. (1997). Elderdesign: Designing and Furnishing a Home for Your Later Years. New York: Penguin Books Publishing.

Burton, E., Mitchell, L., \& Stride, C. (2015). Bed of roses? The role of garden space in older people's well-being. Proceedings of the Institution of Civil Engineers-Urban Design and Planning, 168(4), 164-173.

Cook, C. C., Yearns, M. H., \& Martin, P. (2005). Aging in place: Home modifications among rural and urban elderly. Housing and Society, 32(1), 85106.

Feng, I., Chen, J. H., Zhu, B. W., \& Xiong, L. (2018). Assessment of and improvement strategies for the housing of healthy elderly: Improving quality of life. Sustainability, 10(3), 722.

Fernández-Portero, C., Alarcón, D., \& Padura, Á. B. (2017). Dwelling conditions and life satisfaction of older people through residential satisfaction. Journal of Environmental Psychology, 49, 1-7.

Fiessel, W., Kulyk, M. R., Peel, B., Pfeifer, S., Robert, J. A., \& Statler, K. (2013). Aging in place: A Saskatchewan perspective.SIHL Group Project.
Foster, L., \& Walker, A. (2015). Active and successful aging: A European policy perspective. The Gerontologist, 55(1), 83-90.

Fox, S., Kenny, L., Day, M. R., O’Connell, C., Finnerty, J., \& Timmons, S. (2017). Exploring the housing needs of older people in standard and sheltered social housing. Journal of Gerontology and Geriatric Medicine, 3, 1-14.

Gardner, P. J. (2011). Natural neighborhood networks: Important social networks in the lives of older adults aging in place. Journal of Aging Studies, 25(3), 263-271.

Hadjri, K., Gadakari, T., Huang, J., \& Wang, J. (2018). Age-friendly housing environments. In ODESSA Project End of Award Conference (pp. 14-19). University of Sheffield.

Harrington, T. L., \& Harrington, M. K. (2000). Housing. Gerontechnology: Why and How, Netherlands: Shaker Publishing.

Hazer, O. (2012). Yașlılar için evde bakım ve evde ergonomi: geronteknolojik yaklaşımlar. Kuşaklararası Dayanışma ve Aktif Yaşlanma Sempozyumu, Mart, Ankara, Bildiri Kitabı: 339-347.

İlçe , A. Ö., İlçe, A. C., \& Dıramalı, A. (2007). Yaşlılarda ev kazalarının önlenmesi ve kazalarının önlenmesine yönelik iç mekân çözümlemeleri. Hacettepe Üniversitesi Sosyolojik Araştırmalar E- Dergisi. http://www.sdergi.hacettepe. edu.tr/makaleler/ aiciad.pdf

İmamoğlu, V. (2016). İleri yaşlardaki Türklerin yaşam çevreleri ve daha iyi bir yaşam için öneriler. METU Journal of The Faculty of Architecture, 32(1), 105-119.

Johnson, M., Duncan, R., Gabriel, A., \& Carter, M. (1999). Home modifications and products for safety and ease of use. Design Research and Methods Journal, 1,1 https://projects. ncsu.edu/ncsu/design/cud/pubs_p/docs/Hom e\%20Modifications $\% 20$ and $\% 20$ Products. pdf Erişim Tarihi:12 Nisan 2021.

Kalınkara, V., \& Arpacı, F. (2013). Yerinde yașlanma. VII. Ulusal Yaşlılık Kongresi, 23-25 Mayıs 2013, Karabük. (s. 54-60).

Kalınkara, V., \& Arpacı, F. (2016). Yerinde yașlanma. Ed: V. Kalınkara. Yaşlılık: Disiplinlerarası Yaklașım, Sorunlar, Cözümler-2. Ankara: Nobel Akademik Yayıncılık. (s. 399-422).

Kalınkara, V., \& Kalaycı, I. (2019). Yaşlı sağlığı ve konut. Ed: V. Kalınkara. Yaşlılık Yeni Yüzyılın Gerçeği. Ankara: Nobel Akademik Yayıncılı. (s. 65-93).

Kalınkara, V., \& Kapıkıran, Ş. (2017). Yerinde yaşlanma ölçeğinin geliştirilmesi ve psikometrik özellikleri. Yaşı Sorunları Araştırma Dergisi, 10(2), 54-66.

Kalınkara, V., Tezel, H. E., \& Zorlu, T. (2016). Gero(n)teknoloji: Yaşlı ve teknoloji. (ed: V. Kalınkara). Yaşlılık: Disiplinler arası yaklaşım, sorunlar, çözümler 2. Ankara: Nobel Yayınevi. (s.511-542).

Kirby, S. (2004) A housing safety for checklist for older people. https://content.ces.ncsu.edu/ housing-safety-checklist-for-olderpeople\#section heading 9879. Erişim Tarihi: 11.02.2021. 
Lawlor, D., \& Thomas, M. A. (2008). Residential design for aging in place. John Wiley \& Sons.

Okumuş, M. (2014). Yaşlı Evlerinde Pencerelerin Bina Enerji ve Gün Işığı Performansına Etkisinin Incelenmesi. İstanbul Teknik Üniversitesi, Enerji Enstitüsü, Yüksek Lisans Tezi. İstanbul.

Park, J., \& Porteus, J. (2019). Age-friendly housing: Future design for older people. Riba publishing.

Pinto, M. R., De Medici, S., Zlotnicki, A., Bianchi, A., Van Sant, C., \& Napou, C. (1997). Reduced visual acuity in elderly people: The role of ergonomics and gerontechnology. Age and Ageing, 26(5), 339-344.

Riche, Y. (2008). Designing Communication Appliances to Support Aging in Place. Univ. Paris Sud, Ph. D. Thesis, France.

Şafak, Ş., Erkal, S., \& Çopur, S. (2005). Yaşlılıkta sağlıklı konut ve kazalar. Öz-Veri Dergisi, 2(2),1-15.

Şentürk, M., \& Kurtkapan, H. (2017). Yaşlılığın mekânsallaşması: Kadıköy Moda'daki bir apartman üzerine nitel bir çalıșma. Senex: Yaşlılık Calışmaları Dergisi, 1(1), 4-19.

Talbot, J. F., \& Kaplan, R. (1991). The benefits of nearby nature for elderly apartment residents. The International Journal of Aging and Human Development, 33(2), 119-130.
TUİK, (2021). İstatistiklerle yaşlılar, 2019. https://data.tuik.gov.tr/Bulten/Index ?p=Istatistiklerle-Yaslilar-2020-37227. Erişim Tarihi:14.03.2021.

Vallins, M. (1998). Housing for Elderly People: A Guide for Architects, Interior Designers and Their Clients. London: The Architectural Press Ltd.

WHO, (1989). Health of the elderly. https://apps.who. int/iris/bitstream/handle/10665/39521/ WHO_TRS_779.pdf?sequence $=1$. Erişim Tarihi: 15.02 .2021

WHO, (2007). Global age-friendly cities: $A$ guide. World Health Organization. https://www. who.int/ageing/publications/Global_age friendly_cities_Guide_English.pdf. $\quad$ Erişim Tarihi: 14.11.2021.

Zorlu, T. (2015). Tasarımında kullanıcı faktörü ve ergonomi: Yaşlılar için konut. 1. Ulusal $\dot{I C C}_{c}$ Mimari Tasarım Sempozyumu, 12-13 Ekim 2015, Trabzon. (s. 109-121)

Zorlu, T. (2017). Yaşlılar için konutta iç mekân tasarımı ve ergonomi. Yaşlı Sorunları Araştırma Dergisi, 10(2), 40-53.

Zorlu, T., \& Onur, D. (2019). Yaşlılık ve yașam çevresinin tasarımı. Ed: V. Kalınkara. Yaşlılık Yeni Yüzyılın Gerçeği. Ankara: Nobel Akademik Yayıncilık. (s. 411-435). 